УДК 378.01

DOI: 10.37026/2520-6427-2021-108-4-37-43
Наталя РИСИНЕЦь,

аспірантка кафедри безпеки життєдіяльності та педагогіки безпеки

Вінницького національного технічного університету, м. Вінниия, Украӥна

ORCID: 0000-0002-3015-5834

e-mail: natastavnichaya@gmail.com

\title{
ФОРМУВАННЯ ГОТОВНОСТІ ФАХІВЦІВ 3 МІЖНАРОДНОГО ПРАВА ДО ПРОФЕСІЙНОЇ ДІЯЛЬНОСТІ
}

\begin{abstract}
Анотація. У статті проаналізовано наукові публікації з проблеми моделювання процесу формування готовності фахівиів з міжнародного права до застосування проєктних технологій у професійній діяльності, запропоновано структурно-функиіональну модель формування иієї готовності. До складу розробленоі моделі входять иільовий, теоретико-методологічний, змістовий, процесуальний та результативно-підсумковий компоненти. За результатами аналізу наукових i навчально-методичних джерел, власної практичної діяльності та експертного опитування з проблеми дослідження були визначені основні педагогічні умови формування готовності майбутніх фахівиів з міжнародного права до застосування проєктивних технологій у професійній діяльності: створення навчально-методичного забезпечення; формування
\end{abstract}

суб 'єктно-рефлексивної позииії майбутніх фахівців з міжнародного права; використання методів інтерактивного навчання, щзо моделюють способи професійної взаємодії фахівиів з міжнародного права; поетапне формування готовності до проєктної діяльності шляхом упровадження міжпредметної інтеграції завдяки використанню інформачійних технологій.

Представлено діагностичний апарат для визначення сформованості готовності фахівців з міжнародного права до застосування проєктних технологій: критерії (когнітивний, мотиваційний, рефлексивний, діяльнісний, креативний), рівні (початковий, середній, достатній, креативний) та методика діагностування.

Ключові слова: заклади вищяої освіти, підготовка майбутніх фахівців, міжнародне право, проєктні технології.

\author{
Natalia RYSYNETS, \\ Graduate student of the Department \\ of Life Safety and Safety Pedagogy, \\ Vinnytsia National Technical University, \\ Vinnytsia, Ukraine \\ ORCID: 0000-0002-3015-5834 \\ e-mail: natastavnichaya@gmail.com
}

\section{FORMATION OF READYNESS OF SPECIALISTS IN INTERNATIONAL LAW TO PROFESSIONAL ACTIVITY}

Abstract. The article analyzes scientific publications on the problem of modeling the process of forming the readiness of specialists in international law to apply design technologies in professional activities.

The purpose of the article is to build a model for the formation of project competence of future specialists in international law in higher education institutions.

It has been offered the structural-functional model of formation of this readiness. The developed model includes target, theoretical and methodological, semantic, procedural and result-final components. Based on the analysis of scientific and educational sources, own practical activities and expert survey on the research problem, the main pedagogical conditions for the formation of future specialists in international law to use projective technologies in professional activities were determined: creation of educational and methodological support; formation of the subject-reflexive position of future specialists in international law; use of interactive teaching methods that model ways of professional interaction of specialists in international law; gradual formation of readiness for project activities through the introduction of interdisciplinary integration through the use of information technology.

Theoretical research and practical results of the introduction of project technologies in vocational education confirm that they contribute to the effective formation of all key competencies: cultural, informational, communicative, value-semantic, educational-cognitive, social-labor, personal self-improvement and others.

Also, it has been proposed diagnostic apparatus for determining the readiness of specialists in international law to use project technologies, such as: criteria (cognitive, motivational, reflective, activity, creative), levels (initial, intermediate, sufficient, creative) and diagnostic methods.

Key words: institutions of higher education, training of future specialists, international law, design technologies. 
Постановка проблеми. Нині існує неабияка потреба у створенні нових моделей підготовки майбутніх фахівців, що враховують сучасний розвиток суспільства та забезпечують максимальне використання людського потенціалу. У зв'язку з цим результатом професійної освіти має бути не лише підготовка фахівця, який володіє певним обсягом знань та вмінь і автоматично виконує професійні функції, а передусім компетентної, творчої особистості. Як засвідчив досвід іноземних і вітчизняних дослідників, реалізація у закладах вищої освіти технологій проєктного навчання дозволяє інтегрувати теоретичний і практичний матеріал із різних галузей знань, що сприяє формуванню у майбутніх фахівців досвіду творчої професійної діяльності.

Проєктні технології навчання дозволяють комплексно поєднати пізнавальну та перетворювальну діяльність студентів, залучити їх до активної практичної участі на всіх етапах проєктування, серед яких: формування завдань проєкту та підготовка індивідуальних пропозицій щодо їх реалізації; колективне обговорення висунутих пропозицій («мозковий штурм»); вибір найбільш актуальної чи формування комплексної пропозиції на основі запропонованих, опис рішення та шляхів його оптимальної реалізації; впровадження результатів проєктування у практичну діяльність; аналіз одержаних результатів; коригування запропонованого рішення за результатами проведеного аналізу тощо. Теоретичні дослідження та практичні результати впровадження у професійну освіту проєктних технологій підтверджують, що вони сприяють ефективному формуванню таких ключових компетенцій: загальнокультурної, інформаційної, комунікативної, ціннісно-смислової, навчально-пізнавальної, соціально-трудової, особистого самовдосконалення та ін.

Формування готовності майбутніх фахівців до проєктної діяльності не $є$ універсальним процесом, а потребує врахування фахових особливостей кожної спеціальності, за якою здійснюється професійна підготовка фахівців. Зважаючи на це, для кожної спеціальності загалом та для основних професійно спрямованих дисциплін зокрема потрібно розробити систему методів і цілей реалізації проєктної діяльності, а також сформувати у викладачів відповідні професійні знання та вміння з метою активної практичної участі кожного майбутнього фахівця в означеній діяльності.

Аналіз наукових досліджень і публікацій. Потреба в моделюванні під час досліджень дієвості педагогічних технологій визначена тим, що це дозволяє поєднати теоретичні пошуки шляхів вирішення наукової проблеми із подальшим проведенням практичного дослідження. Підтвердженням цієї тези є результати досліджень низки науковців, які розглядали особливості моделювання педагогічних процесів, зокрема: моделювання освітніх процесів закладів вищої освіти (Д. Айстраханов, Д. Бабанський, Л. Карасьова, О. Борисова, В. Михеєв, Н. Новік) та професійної діяльності (В. Афанасьєва, С. Архангельський, Б. Глинський, О. Заїр-Бек, В. Штофф, Ю. Конаржевський) тощо.

Результати аналізу вітчизняних і зарубіжних досліджень щодо використання проєктних технологій для формування у майбутніх фахівців готовності до професійної діяльності свідчать, що такі наукові розробки для майбутніх фахівців із міжнародного права відсутні. У зв'язку з цим виникає потреба у розробці моделі формування досліджуваної готовності з метою впровадження ії̈ в освітній процес та перевірки ефективності реалізації запропонованих інновацій. Розробка та реалізація моделі формування проєктної компетентності майбутніх фахівців із міжнародного права дозволить удосконалити процес їхньої професійної підготовки, впорядкувати та структурувати його $з$ метою підвищення ефективності формування загальнокультурної та професійної компетентностей здобувачів освіти.

Мета статті полягає в побудові моделі формування проєктної компетентності майбутніх фахівців із міжнародного права в закладах вищої освіти.

Виклад основного матеріалу дослідження. Незважаючи на наявність грунтовних досліджень моделювання як методу наукового пізнання, на сьогодні немає єдиного визначення поняття «модель». У зв'язку з цим пропонуємо ознайомитися із найбільш уживаними варіантами його трактування (див. табл. 1).

Таблиия 1

Трактування поняття «модель» у педагогічних дослідженнях

\begin{tabular}{|c|l|l|}
\hline $\begin{array}{c}\text { № } \\
\text { 3/II }\end{array}$ & \multicolumn{1}{|c|}{ Автор / джерело } & \multicolumn{1}{c|}{ Зміст поняття } \\
\hline 1 & $\begin{array}{l}\text { Великий тлумачний словник } \\
\text { сучасної української мови за } \\
\text { редакцією В. Бусела }\end{array}$ & $\begin{array}{l}\text { уявний чи умовний (зображення, опис, схема тощо) образ якого-небудь об'єкта, } \\
\text { процесу або явища, що використовується як його «представник» (Великий } \\
\text { тлумачний словник сучасної української мови, 2001, с. 535) }\end{array}$ \\
\hline 2 & Краєвський В., Бережнова О. & $\begin{array}{l}\text { система елементів, що відтворює деякі сторони, зв’язки, функції об’єкта } \\
\text { дослідження (Краевский, Бережнова, 2006, с. 333) }\end{array}$ \\
\hline 3 & Штофф В. & $\begin{array}{l}\text { подумки представлена або матеріально реалізована система, що відтворює } \\
\text { об’єкт дослідження, має здатність підміняти його для одержання нової } \\
\text { інформації під час ії вивчення (Штофф, 1966) }\end{array}$ \\
\hline 4 & Маслов В. & $\begin{array}{l}\text { суб’єктивне відтворення у свідомості людини (групи людей) та зовнішнє } \\
\text { відображення різними способами й формами найістотніших ознак, рис і } \\
\text { якостей, що властиві конкретному об'єкту або процесу, які об’єктивно йому } \\
\text { (об’єкту) притаманні та формують загальне уявлення про феномен, який } \\
\text { нас цікавить, або його окремі складники (Теоретичні і методичні засади } \\
\text { моделювання фахової компетентності керівників закладів освіти, 2010) }\end{array}$ \\
\hline
\end{tabular}


Продовження таблийі 1

\begin{tabular}{|c|l|l|}
\hline 5 & Дахін О. & $\begin{array}{l}\text { штучно створений об’єкт у вигляді схем, фізичних конструкцій, знакових } \\
\text { форм чи формул, що, будучи подібним до досліджуваного об'єкта (чи явища), } \\
\text { відображає і відтворює у більш простому й грубому вигляді структуру, } \\
\text { властивості, взаємозв’язки (Дахин, 2004, с. 69) }\end{array}$ \\
\hline 6 & $\begin{array}{l}\text { Шандригось Г. } \\
\text { речова, знакова або мисленнєва система, що відтворює, імітує, відображає } \\
\text { принципи внутрішньої організації або функціонування об’єкта, його } \\
\text { властивості, ознаки чи характеристики (Шандригось) }\end{array}$ \\
\hline 7 & Кочергін О. & $\begin{array}{l}\text { уявна чи матеріально втілена система, яка відтворює об’єкт дослідження і } \\
\text { здатна замінити його настільки, що й сама стає джерелом нової дослідницької } \\
\text { iнформації (Кочергин, 1969) }\end{array}$ \\
\hline
\end{tabular}

Як бачимо $з$ таблиці 1, поняття «модель» учені розглядають із двох позицій: як об'єкт та як систему. Вибір трактування залежить від особливостей об'єкта дослідження та завдань, які ставить перед собою науковець. Зважаючи на теоретичні положення нашого наукового пошуку, представлені вище, схиляємося до того, що модель - це зображення у вигляді знакових форм, що відображає принципи функціонування освітнього середовища, рис і якостей, які йому властиві, та дозволяє відтворити реально існуючі взаємозв'язки 3 метою отримання нової дослідницької інформації.

На сьогодні розроблено декілька основних класифікацій моделей. Найбільш прийнятною в контексті нашого дослідження вважаємо класифікацію за А. Вєдєновим (1988), який виділяє такі типи моделей: субстанціональні, структурні, функціональні та змішані. Як свідчать теоретичні пошуки, найбільш поширеними в педагогічних дослідженнях є змішані моделі, зокрема структурно-функціональна, оскільки саме вона дає змогу максимально врахувати особливості освітніх процесів та проєктувати формування бажаної властивості учнів / студентів.

Також немає єдності й у трактуванні поняття «педагогічне моделювання», в чому ми можемо пересвідчитися, розглянувши таблицю 2.

Таблиия 2

Трактування поняття «педагогічне моделювання» в педагогічних дослідженнях

\begin{tabular}{|c|l|l|}
\hline $\begin{array}{c}\text { № } \\
\text { 3/п }\end{array}$ & \multicolumn{1}{|c|}{ Автор / джерело } & \multicolumn{1}{c|}{ Зміст поняття } \\
\hline 1 & $\begin{array}{l}\text { Педагогічний } \\
\text { словник за редакцією } \\
\text { М. Ярмаченка }\end{array}$ & $\begin{array}{l}\text { процес дослідження певних явищ, процесів або систем об’єктів шляхом побудови } \\
\text { та вивчення їніх моделей. Моделювання належить до основних категорій пізнання, } \\
\text { на якому грунтуться як теоретичний, так і експериментальний методи наукового } \\
\text { дослідження (Педагогічний словник, 2001, с. 206) }\end{array}$ \\
\hline 2 & Семенова О. & процес створення, дослідження та використання моделі (Семенова, 2015, с. 301) \\
\hline 3 & Гончаренко С. & $\begin{array}{l}\text { науково обгрунтоване конструювання, що відповідає заданим вимогам і наміченій } \\
\text { побудові майбутної моделі досліджуваного педагогічого процесу, враховуючи } \\
\text { властивості, що вивчаються в ході педагогічного експерименту (Гончаренко, 2011, } \\
\text { с. 213) }\end{array}$ \\
\hline 4 & $\begin{array}{l}\text { Галатюк Ю., } \\
\text { Тищук В. }\end{array}$ & $\begin{array}{l}\text { уміння нестандартно організовувати навчання (пізнавальну діяльність) з будь-якого } \\
\text { предмета; об’єднання різних видів діяльності та організація навчального процесу в } \\
\text { межах одного уроку вимагає від учителя творчих зусиль та відповідної теоретичної } \\
\text { підготовки (Галатюк, Тищук, 2005, с. 308) }\end{array}$ \\
\hline & Шапран Ю. & $\begin{array}{l}\text { метод опосередкованого пізнання за допомогою штучно створених і природних } \\
\text { систем, які зберігають деякі особливості об’єкта дослідження, дають можливість } \\
\text { репрезентувати його у певних відношеннях та надати про нього нові знання (Шапран, } \\
\text { 2012, с. 42) }\end{array}$ \\
\hline
\end{tabular}

Аналіз таблиці 2 показує, що і в цьому випадку існують два основні підходи до трактування досліджуваного терміна, зокрема педагогічне моделювання трактується науковцями як процес створення та дослідження моделі або як метод опосередкованого пізнання (див. табл. 3).

Отже, вважаємо, що ці два підходи неподільні та доповнюють один одного, оскільки на підставі створеної моделі відбувається подальше опосередковане пізнання властивостей освітнього середовища.
Варто зауважити, що більшість педагогічних досліджень були спрямовані на формування готовності до провадження проєктної діяльності в майбутніх учителів. Це пояснюється специфікою їхньої майбутньої професійної діяльності, зокрема потребою навчити дітей створювати та реалізовувати проєкти. Однак метод проєктів має значні перспективи й для професійної діяльності фахівців із міжнародного права. 


\section{Аналіз структури моделей формування готовності до просктної діяльності майбутніх фахівців із міжнародного права}

\begin{tabular}{|c|c|c|c|}
\hline $\begin{array}{l}\text { № } \\
\text { 3/II }\end{array}$ & Автор & Напрям наукового пошуку & Структурні компоненти моделі \\
\hline 1 & Жиле Л. & $\begin{array}{l}\text { формування готовності вчителів філоло- } \\
\text { гічних спеціальностей до проєктної ді- } \\
\text { яльності в умовах науково-методичної } \\
\text { роботи школи }\end{array}$ & $\begin{array}{l}\text { мета, організаційний блок (нормативно-правове за- } \\
\text { безпечення, методологічні підходи, організаційно-пе- } \\
\text { дагогічні умови), технологічний блок, діагностичний } \\
\text { блок (рівні, критерії, тестова методика), результат } \\
\text { (Жиле, 2019). }\end{array}$ \\
\hline 2 & Власенко А. & $\begin{array}{l}\text { підготовка майбутніх учителів іноземної } \\
\text { мови до проєктної діяльності в початковій } \\
\text { школі }\end{array}$ & $\begin{array}{l}\text { методологічно-цільовий блок (мета, завдання, } \\
\text { основні принципи та підходи щодо підготовки } \\
\text { майбутніх учителів іноземної мови до проєктної } \\
\text { діяльності); змістово-процесуальний блок (зміст } \\
\text { підготовки майбутніх учителів іноземної мови до } \\
\text { проєктної діяльності, форми, методи, засоби та } \\
\text { технології навчання); результативно-оцінний блок } \\
\text { (критерії, рівні готовності та результат) (Власенко, } \\
\text { 2017) }\end{array}$ \\
\hline 3 & Давидова С. & $\begin{array}{l}\text { формування професійної компетентності } \\
\text { майбутніх учителів образотворчого } \\
\text { мистецтва засобами творчої проєктної } \\
\text { діяльності }\end{array}$ & $\begin{array}{l}\text { мета, завдання, умови (психологічні, педагогічні, } \\
\text { соціальні), об’єкти та результат (Давидова, 2019) }\end{array}$ \\
\hline 4 & Левіна I. & $\begin{array}{l}\text { модель формування проєктної компе- } \\
\text { тентності майбутніх учителів у процесі } \\
\text { професійної підготовки }\end{array}$ & $\begin{array}{l}\text { цільовий, змістовий, технологічний та аналітико- } \\
\text { результативний блоки (Levina, 2016) }\end{array}$ \\
\hline 5 & Мельничук Ю. & $\begin{array}{l}\text { формування проєктно-аналітичної компе- } \\
\text { тентності майбутніх офіцерів-прикордон- } \\
\text { ників у процесі фахової підготовки }\end{array}$ & $\begin{array}{l}\text { цільовий, змістовий, результативний блоки; окремо } \\
\text { винесені педагогічні умови як об’єднувальний } \\
\text { елемент усіх блоків (Мельничук, 2018) }\end{array}$ \\
\hline 6 & $\begin{array}{l}\text { Парфьонова Т., } \\
\text { Севенюк С. }\end{array}$ & $\begin{array}{l}\text { формування проєктної компетентності } \\
\text { майбутніх педагогів початкової школи }\end{array}$ & $\begin{array}{l}\text { цільовий, методологічний, змістовий, організацій- } \\
\text { но-діяльнісний, результативно-оцінювальний ком- } \\
\text { поненти (Парфенова, Севенюк, 2019) }\end{array}$ \\
\hline 7 & $\begin{array}{l}\text { Слугина Н., } \\
\text { Чернявська В. }\end{array}$ & $\begin{array}{l}\text { формування рефлексивно-проєктної } \\
\text { компетенції у майбутніх бакалаврів } \\
\text { інформаційно-технологічного напряму }\end{array}$ & $\begin{array}{l}\text { цільовий, змістовий, технологічний, критеріально- } \\
\text { результативний компоненти (Слугина, Чернявская, } \\
\text { 2014) }\end{array}$ \\
\hline
\end{tabular}

Побудова педагогічних проєктів здійснюється переважно за таким алгоритмом:

- визначення мети або побудова цільового блоку, в межах якого визначається мета та завдання;

- окреслення 3-4 блоків, до яких зазвичай включають: змістовий (відображає зміст досліджуваного явища, його характеристики); технологічний або діяльнісний (передбачає визначення операцій і способів дії з метою формування бажаних властивостей); критеріальний або оцінювальний (визначає специфіку діагностування досліджуваного явища, критерії ефективності запропонованих інновацій тощо);

- визначення прогнозованого результату.

Слід зазначити, що в більшості моделей коригувальні заходи не передбачені. Вважаємо такий підхід хибним, адже у процесі реалізації моделей у реальних освітніх умовах здебільшого виникають певні проблеми, що потребуватимуть корекції. Таким чином, щоб модель була дієвою та коректною, вона повинна передбачати можливість коригувальних дій у ході ії реалізації.

Створена структурно-функціональна модель формування готовності майбутніх фахівців із міжнародного права до застосування проєктних технологій у професійній діяльності представлена нами на рисунку.
Зважаючи на викладене вище, зауважимо, що до складу представленої нами моделі (див. рис.) входять такі компоненти: цільовий, теоретикометодологічний, змістовий, процесуальний та результативно-підсумковий.

Цільовий компонент визначається метою та завданнями підготовки майбутніх фахівців 3 міжнародного права до застосування проєктивних технологій у професійній діяльності. Відповідно його метою $€$ формування готовності майбутніх фахівців з міжнародного права до застосування проєктивних технологій у професійній діяльності, а основними завданнями:

- підготовка висококваліфікованих фахівців з міжнародного права, готових до провадження успішної професійної діяльності;

- надання студентам грунтовних знань про проєктивні технології та напрями їх використання у професійній діяльності;

- формування в студентів умінь та навичок щодо застосування проєктивних технологій у професійній діяльності;

- пошук ефективних методів навчання, які забезпечують формування професійної компетентності майбутніх фахівців 3 міжнародного права. 


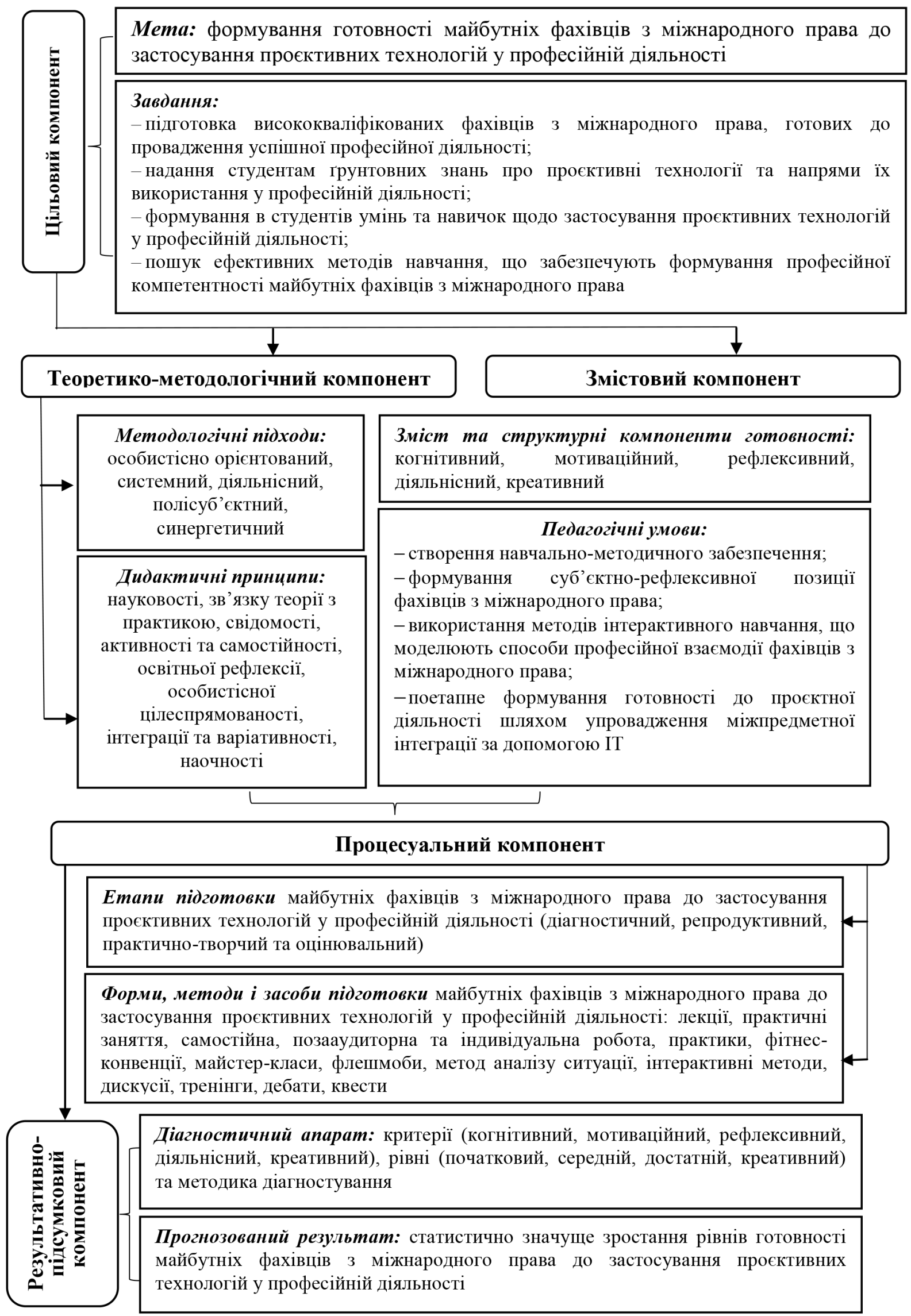

Рис. Структурно-функиіональна модель формування готовності майбутніх фахівиів з міжнародного права до застосування проєктних технологій у професійній діяльності 
Теоретико-методологічний компонент визначається методологічними підходами та дидактичними принципами, які мають бути враховані в процесі формування готовності майбутніх фахівців 3 міжнародного права до застосування проєктивних технологій у професійній діяльності 3 метою забезпечення максимальної ефективності означеного процесу. До методологічних підходів, ураховуючи особливості започаткованого дослідження, віднесено: особистісно орієнтований, системний, діяльнісний, полісуб'єктний, синергетичний. Для досягнення поставленої мети було визначено необхідність урахування таких дидактичних принципів: науковості, зв'язку теорії з практикою, свідомості, активності й самостійності, особистісної цілеспрямованості, освітньої рефлексії, інтеграції та варіативності, наочності.

Змістовий компонент передбачає визначення змісту та структурних компонентів готовності (когнітивний, мотиваційний, рефлексивний, діяльнісний, креативний), а також окреслення відповідних педагогічних умов формування готовності майбутніх фахівців 3 міжнародного права до застосування проєктивних технологій у професійній діяльності.

Проиесуальний компонент включає етапи формування готовності майбутніх фахівців з міжнародного права до застосування проєктивних технологій у професійній діяльності (діагностичний, репродуктивний, практично-творчий та оцінювальний), а також форми, методи і засоби підготовки майбутніх фахівців з міжнародного права до застосування проєктивних технологій у професійній діяльності (лекції, практичні заняття, самостійна, позааудиторна та індивідуальна робота, практики, фітнес-конвенції, майстер-класи, флешмоби, метод аналізу ситуації, інтерактивні методи, дискусії, тренінги, дебати, квести).

Діагностичний етап передбачає визначення початкового рівня сформованості готовності майбутніх фахівців 3 міжнародного права до застосування проєктивних технологій у професійній діяльності та формування у майбутніх фахівців 3 міжнародного права мотивації до провадження проєктної діяльності в процесі навчання як засобу підвищення професійної компетентності.

На репродуктивному етапі забезпечувалося набуття знань та формування умінь і навичок проєктної діяльності. Практично-творчий етап полягав у виконанні індивідуальних проєктів у процесі наукової роботи та виробничої практики, що дало можливість узагальнити наявні знання проєктної технології та застосувати їх в умовах, максимально наближених до професійної діяльності.

Оцінювальний етап формування готовності майбутніх фахівців з міжнародного права до застосування проєктивних технологій у професійній діяльності передбачав аналіз ефективності запропонованих інновацій та здійснення корегувальних заходів відповідно до отриманих результатів.

Результативно-підсумковий компонент відображає діагностичний апарат, до якого віднесено: критерії (когнітивний, мотиваційний, рефлексивний, діяльнісний, креативний); рівні (початковий, середній, достатній, креативний) та методика діагностування); прогнозований результат (статистично значуще зростання рівнів готовності майбутніх фахівців з міжнародного права до застосування проєктивних технологій у професійній діяльності).

Висновки. За результатами теоретичних досліджень нами було побудовано структурно-функціональну модель формування готовності майбутніх фахівців 3 міжнародного права до застосування проєктних технологій у професійній діяльності, що містить цільовий, теоретико-методологічний, змістовий, процесуальний і результативно-підсумковий компоненти та спрямована на забезпечення зростання рівнів готовності згаданих вище фахівців. Статистичний аналіз результатів камерного педагогічного експерименту, проведеного в реальних умовах освітнього процесу у Вінницькому кооперативному інституті, підтвердив дієвість запропонованої моделі.

Перспективи подалыших досліджень вбачаємо в експериментальній перевірці запропонованої структурно-функціональної моделі формування готовності майбутніх фахівців з міжнародного права до застосування проєктних технологій у професійній діяльності в закладах вищої освіти, які здійснюють підготовку фахівців за цією спеціальністю, для ії подальшого вдосконалення та можливості застосування під час підготовки фахівців 3 різних галузей права.

\section{СПИСОК ВИКОРИСТАНОЇ ЛІТЕРАТУРИ}

Великий тлумачний словник сучасної української мови. (2001) / уклад. і гол. ред. В. Т. Бусел. Київ; Ірпінь: Перун. 1440 с.

Краевский, В. В., Бережнова, Е. В. (2006). Методология педагогики: новый этап: учеб. пособие для студ. высш. учеб. заведений. Москва: Академия. 400 с.

Штофф, В. А. (1966). Моделирование и философия. Ленинград: Наука. 302 с.

Теоретичні і методичні засади моделювання фахової компетентності керівників закладів освіти: монографія. (2010) / Г. В. Сльникова, О.І.Зайченко, В. І. Маслов та ін.; за ред. Г. В. Сльникової. Київ; Чернівці: Книги - XXI. 460 с.

Дахин, А. Н. (2004). Педагогическое моделирование: сущность, эффективность и неопределенность: теория и практика образовательной технологии. Москва: НИИ школьных технологий. С. 65-93.

Шандригось, Г. А. (2012). Можливості моделювання у професійній підготовці майбутнього вчителя фізичної культури. URL: www.nbuv.gov.ua/portal/ Soc_Gum/ Vchdpu/2012_98.../Shand.pdf (дата звернення: 23.09.2021).

Кочергин, А. Н. (1969). Моделирование мышления. Москва: Наука. 96 с.

Педагогічний словник. (2001) / за ред. М. Д. Ярмаченка. Київ: Педагогічна думка. С. 323.

Семенова, О. В. (2015). Педагогічне моделювання: функції та складові. Наукові записки Бердянського державного педагогічного університету. Вип. 3. С. 299-305.

Гончаренко, С. У. (2011). Український педагогічний енциклопедичний словник. 2-е вид., доп. і випр. Рівне: Волинські обереги. 552 с.

Галатюк, Ю., Тищук, В. (2005). Підготовка майбутніх учителів фізики до творчої професійної діяльності. Вісник Львівського університету. Серія «Педагогічна». Вип. 19. Ч. 1. С. 307-313.

Шапран, Ю. (2012). Педагогічне моделювання у процесі формування професійної компетентності 
майбутнього вчителя біології. Рідна школа. № 12. С. $39-43$.

Жиле, Л. (2019). Формування готовності вчителів філологічних спеціальностей до проектної діяльності в умовах науково-методичної роботи загальноосвітніх навчальних закладів: автореф. дис. ... канд. пед. наук: 13.00.04. Рівне. 20 c.

Власенко, А. О. (2017). Підготовка майбутніх учителів іноземної мови до проектної діяльності в початковій школі: дис. ... канд. пед. наук: 13.00.04. Умань. 278 с.

Давидова, С. (2019). Модель формування професійної компетентності майбутніх учителів образотворчого мистецтва засобами творчої проектної діяльності. Проблеми підготовки сучасного вчителя: збірник наукових праць. Вип. 1 (19). С. 54-63.

Levina, I. (2016). The model of future teachers' project competence formation in the process of professional training. Наука і освіта. № 10. С. 24-29.

Мельничук, Ю. П. (2018). Формування проектноаналітичної компетентності майбутніх офіцерів-прикордонників у процесі фахової підготовки: автореф. дис. ... канд. пед. наук: 13.00.04. Хмельницький. 20 с.

Парфенова, Т. А., Севенюк, С. А. (2019). Формирование проектной компетентности будущих педагогов начальной школы в процессе высшего образования. Самарский научный вестник. Т. 8. № 1 (26). С. 282-288.

Слугина, Н. Л., Чернявская, В. С. (2014). Модель формирования рефлексивно-проектной компетенции у будущих бакалавров информационно-технологического направления. Успехи современного естествознания. № 5. Ч. 2. С. 160-165.

Веденов, А. А. (1988). Моделирование элементов мышления. Москва: Наука. 334 с.

\section{REFERENCES}

Velykyi tlumachnyi slovnyk suchasnoi ukrainskoi movy [Great explanatory dictionary of modern Ukrainian language]. (2001)/ uklad. i hol. red. V. T. Busel. Kyiv; Irpin: Perun. 1440 s. [in Ukrainian].

Kraevskiy, V. V., Berezhnova, Ye. V. (2006). Metodologiya pedagogiki: novyy etap [Methodology of pedagogy. New stage]: ucheb. posobie dlya stud. vyssh. ucheb. zavedeniy. Moskva: Akademiya. 400 s. [in Russian].

Shtoff, V. A. (1966). Modelirovanie i filosofiya [Modeling and philosophy]. Leningrad: Nauka. 302 s. [In Russian].

Teoretychni i metodychni zasady modeliuvannia fakhovoi kompetentnosti kerivnykiv zakladiv osvity [Theoretical and methodical bases of modeling of professional competence of heads educational institutions]: monohrafiia. (2010)/ H. V. Yelnykova, O. I. Zaichenko, V. I. Maslov ta in.; za red. H. V. Yelnykovoi. Kyiv; Chernivtsi: Knyhy - XXI. 460 s. [in Ukrainian].

Dakhin, A. N. (2004). Pedagogicheskoe modelirovanie: sushchnost, effektivnost i neopredelennost: teoriya i praktika obrazovatelnoy tekhnologii [Pedagogical modeling: essence, efficiency and uncertainty. Theory and practice of educational technology]. Moskva: NII shkolnykh tekhnologiy. S. 65-93. [in Russian]

Shandryhos, H. A. Mozhlyvosti modeliuvannia u profesiinii pidhotovtsi maibutnoho vchytelia fizychnoi kultury [Opportunities of modeling in professional training of the future teacher of physical culture]. URL: www.nbuv.gov.ua/portal/ Soc_Gum/ Vchdpu/2012_98.../Shand.pdf (data zvernennia: 23.09.2021). [in Ukrainian].

Kochergin, A. N. (1969). Modelirovanie myshleniya [Modeling of thinking]. Moskva: Nauka. 96 s. [in Russian].
Pedahohichnyi slovnyk [Pedagogical vocabulary]. (2001) / za red. M. D. Yarmachenka. Kyiv: Pedahohichna dumka. S. 323. [in Ukrainian].

Semenova, O. V. (2015). Pedahohichne modeliuvannia: funktsii ta skladovi [Pedagogical model: functions and warehouses]. Naukovi zapysky Berdianskoho derzhavnoho pedahohichnoho universytetu. Vyp. 3. S. 299-305. [in Ukrainian].

Honcharenko, S. U. (2011). Ukrainskyi pedahohichnyi entsyklopedychnyi slovnyk [Ukrainian pedagogical vocabulary]. 2-e vyd., dop. i vypr. Rivne: Volynski oberehy. 552 s. [in Ukrainian].

Halatiuk, Yu., Tyshchuk, V. (2005). Pidhotovka maibutnikh uchyteliv fizyky do tvorchoi profesiinoi diialnosti [Preparation of future physics teachers for creative professional activity]. Visnyk Lvivskoho universytetu. Ceriia «Pedahohichna». Vyp. 19. Ch. 1. S. 307-313. [in Ukrainian].

Shapran, Yu. (2012). Pedahohichne modeliuvannia u protsesi formuvannia profesiinoi kompetentnosti maibutnoho vchytelia biolohii [Pedagogical modeling in the process of forming professional competence of future biology teacher]. Ridna shkola. № 12. S. 39-43. [in Ukrainian].

Zhyle, L. (2019). Formuvannia hotovnosti vchyteliv filolohichnykh spetsialnostei do proektnoi diialnosti v umovakh naukovo-metodychnoi roboty zahalnoosvitnikh navchalnykh zakladiv [Formation of readiness of teachers of philological specialties to project activity in the conditions of scientific and methodical work of general educational institutions]: avtoref. dys. ... kand. ped. nauk: 13.00.04. Rivne. 20 s. [in Ukrainian].

Vlasenko, A. O. (2017). Pidhotovka maibutnikh uchyteliv inozemnoi movy do proektnoi diialnosti v pochatkovii shkoli [Preparation of future foreign language teachers for project activities in primary school]: dys. ... kand. ped. nauk: 13.00.04. Uman. 278 s. [in Ukrainian].

Davydova, S. (2019). Model formuvannia profesiinoi kompetentnosti maibutnikh uchyteliv obrazotvorchoho mystetstva zasobamy tvorchoi proektnoi diialnosti [Model of formation of professional competence of future teachers of fine arts by means of creative project activity]. Zbirnyk naukovykh prats problemy pidhotovky suchasnoho vchytelia. Vyp. 1 (19). S. 54-63. [in Ukrainian].

Levina, I. (2016). The model of future teachers project competence formation in the process of professional training. Nauka i osvita. № 10. S. 24-29. [in English].

Melnychuk, Yu. P. (2018). Formuvannia proektno-analitychnoi kompetentnosti maibutnikh ofitseriv-prykordonnykiv $\mathrm{u}$ protsesi fakhovoi pidhotovky [Formation of project and analytical competence of future border guards in the process of professional training]: avtoref. dys. ... kand. ped. nauk: 13.00.04. Khmelnytskyi. 20 s. [in Ukrainian].

Parfenova, T. A., Sevenyuk, S. A. (2019). Formirovanie proektnoy kompetentnosti budushchikh pedagogov nachalnoy shkoly v protsesse vysshego obrazovaniya [Formation of project competence of future primary school teachers in the process of higher education]. Samarskiy nauchnyy vestnik. T. 8. № 1 (26). S. 282-288. [in Russian].

Slugina, N. L., Chernyavskaya, V. S. (2014). Model formirovaniya refleksivno-proektnoy kompetentsii u budushchikh bakalavrov informatsionno-tekhnologicheskogo napravleniya [Formation of project competence of future primary school teachers in the process of higher education]. Uspekhi sovremennogo estestvoznaniya. № 5. Ch. 2. S. 160-165. [in Russian].

Vedenov, A. A. (1988). Modelirovanie elementov myshleniya [Modeling of thinking elements]. Moskva: Nauka. 334 s. [in Russian].

Дата надходження до редакиії: 25.09.2021 p. 